Andragogi: Jurnal Ilmiah Pendidikan Agama Islam http://riset.unisma.ac.id/index.php/ja/issue/view $\underline{1696}$

Volume 2 Nomor 2 Tahun 2020

e-ISSN: 2655-948X

http://u.lipi.go.id/1548306171

\title{
PENGEMBANGAN PENDIDIKAN AGAMA ISLAM MELALUI MANAJEMEN LEMBAGA PENDIDIKAN ISLAM PONDOK PESANTREN AL-KAROMAH, KEPANJEN MALANG
}

\author{
Siti Muawanatul Hasanah \\ Universitas Islam Raden Rahmat Malang \\ e-mail: nunung85@gmail.com
}

Diterima: 05 November 2020 | Direvisi: 27 November 2020 | Disetujui: 28 November 2020

(C) 2018 Program Studi Pendidikan Agama Islam Fakultas Agama Islam Universitas Islam Malang

\begin{abstract}
This study aims to explore and analyze the typology of management of Islamic educational institutions in the archipelago. This qualitative descriptive study made the kyai the research subject. The collection technique was carried out by observation, interviews, and documentation. While the analysis is done by collecting research data, reducing data, presenting data to draw conclusions. The results show that the typology of management of Islamic education institutions in the archipelago is: 1) The development of Islamic boarding schools tends to be modern, this can be seen from the pesantren curriculum whose development tends to develop madrasah diniyah which are divided into madrasah diniyah at ula, wustha, and ulya levels. Not only the development of the madrasah diniyah, the curriculum development in the Al-Karomah Islamic boarding school has also developed a pesantren curriculum that is macro, meso and micro. 2) The leadership pattern played by the kyai tends to a charismatic type of leadership, this can be seen in several activity structures that involve the figure of the kyai directly in the field. Kyai also acts as an intellectual leader, as a community leader, and as a spiritual leader.
\end{abstract}

Keywords: PAI, Islamic education management, pesantren

\begin{abstract}
Abstrak
Penelitian ini bertujuan untuk menggali dan menganalisis tipologi pengelolaan lembaga pendidikan Islam di nusantara. Studi deskriptif kualitatif ini menjadikan kyai sebagai subjek penelitian. Teknik pengumpulan data dilakukan dengan observasi, wawancara, dan dokumentasi. Sedangkan analisis dilakukan dengan cara mengumpulkan data penelitian, mereduksi data, menyajikan data hingga menarik kesimpulan. Hasil penelitian menunjukkan bahwa tipologi pengelolaan lembaga pendidikan Islam di nusantara adalah: 1) Perkembangan pesantren cenderung modern, hal ini terlihat dari kurikulum pesantren yang perkembangannya cenderung mengembangkan madrasah diniyah yang terbagi menjadi madrasah. diniyah pada tingkat ula, wustha, dan ulya. Tidak hanya pengembangan madrasah diniyah, pengembangan kurikulum di pesantren Al-Karomah juga telah mengembangkan kurikulum pesantren yang bersifat makro, meso dan mikro. 2) Pola kepemimpinan yang dimainkan oleh kyai cenderung pada tipe kepemimpinan yang karismatik, hal ini terlihat pada beberapa struktur kegiatan yang melibatkan sosok kyai secara langsung di lapangan.
\end{abstract}

This work is licensed under Creative Commons Attribution Non Commercial 4.0 International License Available online on: http://riset.unisma.ac.id/index.php/fai/index 
Kyai juga berperan sebagai pemimpin intelektual, pemimpin komunitas, dan pemimpin spiritual.

Kata Kunci: PAI, manajemen pendidikan Islam, pesantren

\section{Pendahuluan}

Indonesia adalah Negara kepulauan yang luasnya termasuk urutan ke-4 setelah cina, india, dan amerika (Nata, 2011: 235). Luasnya wilayah Indonesia menjadikan keberagaman suku, ras, agama, dan budaya termasuk disini adalah berbeda juga pengembangan lembaga pendidikan pada masing masing daerah yang berada di Indonesia. Sejarah pendidikan Islam di Indonesia akan selalu berjalan dan berkembang seiring dengan berkembangnya Islam itu sendiri. Mengapa demikian, Hal ini dapat dilihat dari komunitas yang ada dan terbangun didalamnya, setiap ada komunitas Muslim yang saling bertemu dan menduduki suatu daerah atau wilayah tertentu, maka di sanalah akan ada pendidikan Islam yang akan terbangun dan berkembang. Selanjutnya setelah masyarakat Islam telah terbentuk, maka yang menjadi perhatian utama dan pertama adalah adalah membangun rumah ibadah yaitu masjid, surau atau langgar dan membangun lembaga pendidikan Islam. Maka sesungguhnya dapat kita ketahui bersama bahwa pendidikan Islam itu ada sejak Islam masuk ke Indonesia (Daulay, 2002: 3).

Melalui Lembaga pendidikan Islam, materi pendidikan agama Islam tumbuh subur di ajarakan pada masyarakat Indonesia. Ajaran itu menjadikan bangsa Indonesia memiliki identitas sesuai dengan hakikat masyarakat negara, yakni bangsa beradab. Model masyarakat demikian tidak terlepas dari etika dan estetika yang ditampilkan melalui sopan santun dalam bertindak maupun berbicara. Sebagaimana munculnya bahasa halus pada masing-masing daerah atau wilayah di Indonesia sebagai identitas masyarakat beradab. Hal ini pula tidak terlepas dari materi pendidikan agama Islam yang diberikan kepada masyarakat melalui Lembaga pendidikan Islam sebelum Indonesia merdeka. Dan umat Islam Indonesia sebagai masyarakat mayoritas, sehingga dapat menentukan identitas suatu negara. Disinilah peluang lembaga pendidikan Islam di Indonesia dalam mendidik, membina, maupun mempebeerdayakan pemeluknya untuk menjadi bangsa beradab (Hidayatullah MF, 2020: 261)

Sejalan bertambahnya populasi umat Islam Indonesia berdampak pada tumbuh kembangnya Lembaga pendidikan Islam. Manusia adalah mahluk ciptaan tuhan yang dibekali akal dan naluri untuk mengembangkan potensi dirinya dalam hal ini mengembangkan komunitas diri sebagai seorang muslim dengan membuat dan membentuk lembaga pendidikan. Lembaga sebagai komponen vital yang 
memiliki kontribusi besar dalam pelaksanaan pendidikan. Sebagaimana pandangan Daulay tentang tipologi Lembaga pendidikan Islam terdiri atas, formal, informal, dan non formal. Ketiganya dituntut bersinergi dalam menciptakan manusia sempurna melalui alat pendidikan. Awalnya Lembaga Pendidikan Islam tidak sebagaimana saat ini. Walaupun berbentuk non formal, akan tetapi kontirubusi yang diberikan bangsa dan negara sangat berharga dan membawa kemajuan dan perkembangan pendidikan Indonesia umumnya dan pendidikan Islam khususnya. Dan seiring perkembangnnya sebagaimana saat ini Lembaga pendidikan Islam dapat dipertaruhkan mutu dan kemajuannya.

Dapat kita asumsikan bersama perkembangan lembaga pendidikan saat ini tidak lepas dari bagaimana kita membuat konsep, menjalankan, mengembangkan, dan menjaganya, sehingga lembaga pendidikan Islam menjadi digandrungi atau diminati oleh masyarakat luas. Maka penting kiranya, untuk mempertahankan eksistensi lembaga pendidikan saat ini. Untuk itu kita perlu mengetahui tipologi manajemen lembaga pendidikan Islam itu sendiri, khususnya di Nusantara dengan tujuan setelah kita mengetahui macam-macam tipe lembaga pendidikan Islam yang ada di Nusantara, sebagai praktisi pendidikan, kita bisa berperan sebagai manager dan pemimpin, serta menjadi pemerhati dunia pendidikan Islam.

Salah satu dari lembaga pendidan Islam yang ada saat ini adalah pesantren yang dalam kategorinya masuk pada pendidikan nonformal. Pesantren diartikan sebagai tempat belajar yang mengajarkan penekanan pada ajaran dan nilai agama Islam. Pesantren didefinisikan Lembaga pendidikan Islam yang tumbuh dalam bentuk asrama dengan mendapatkan pengakuan masyarakat keberadannya dan mengajarkan penguasaan terhadap materi pendidikan agama Islam yang dipimpin langsung oleh kyai dengan kharismatik sifatnya serta independen dalam segala hal. Lembaga Islam mengartikan pesantren sebagai tempat tinggal dan berkumpulnya para santri untuk menerima pelajaran agama Islam.

Manajemen pendidikan adalah suatu sistem pengelolaan dan penataan sumber daya pendidikan, seperti tenaga kependidikan, peserta didik, masyarakat, kurikulum, dana keuangan, sarana dan prasarana pendidikan, tata laksana dan lingkungan pendidikan. Manajemen pendidikan Islam didefinisikan proses pengelolaan dan penataan lembaga pendidikan Islam dalam rangka mencapai tujuan pendidikan Islam dengan melibatkan sumber daya manusia muslim. Dalam mengembangkan sebuah lembaga pendidikan Islam tidak boleh dilaksanakan secara asal-asalan. Hal ini merupakan prinsip utama dalam ajaran Islam. Rasulullah saw, bersabda dalam sebuah hadits yang artinya; "Sesungguhnya Allah sangat 
mencintai orang yang jika melakukan sesuatu pekerjaan dilakukan secara Itqan". (HR.Thabrani) (Soebahar, 2013: 53).

Hari ini, pesantren harus responsif terhadap kebutuhan tantangan zaman. Seyogyanya pertumbuhan dan perkembangan pesantren diarahkan kepada fungsionalisasi atau lebih tepatnya adalah refunsionalisasi yaitu pesantren sebagai salah satu pusat penting bagi pembangunan masyarakat. Dengan posisi dan kedudukan pesantren yang khas, pesantren diharapkan menjadi alternative pembangunan yang berpusat pada masyarakat itu sendiri (people-centered development) dan sekaligus sebagai pusat pembangunan karakter pada santri sehingga pembelajaran agama Islam dapat diaktualisasikan dalam kehidupan sehari-hari. Inilah yang disebut dengan (value-oriented development) pusat pembangunan yang berorientasi pada sebuah nilai.

Sejalan dengan penikiran diatas, beberapa pesantren yang ada saat ini telah menerapkan dan melaksanakan sistem kelembagaan modern dipesantrennya masing-masing yang ditandai dengan pola kepemimpinan yang dibangun dipesantren, termasuk dalam hal ini adalah pola kepemimpinan kyai di pondok pesantren Al-Karomah kepanjen malang yang mana pada pengembangan lembaga pendidikan dipesantren tersebut menggunakan tipologi pengembangan model pesantren modern.

\section{Metode}

Pada penelitian ini, jenis penelitian yang digunakan adalah kualitatif deskriptif dengan mendeskripsikan kata-kata yang didaptkan baik tertulis maupun lisan serta tinndakan hasil pengamatan (Danim, 2002: 51). Adapun pengumpulan data penelitiannya melalui observasi, wawancara dan dokumentasi. Sementara analisis datanya, peneliti menggunakan tiga langkah yang saling berkaitan seperti: reduksi data, penyajian data, serta penarikan kesimpulan atau verifikasi (Usman, 2009: 8589). Selanjutnya pengecekan keabsahan data, peneliti menggunakan pengamatan, ketekunan pengamatan, dan triangulasi.

\section{Hasil dan Pembahasan}

\section{Pengembangan Kurikulum PAI di Pesantren Al-Karomah Kepanjen Malang}

Di pondok pesantren Al-Karomah, pengembangan PAI di pesantren dengan mengembangakan konsep pesantren secara modern melalui pengembangan madrasah yang menjadi salah satu perioritas utama di Al-Karomah tersebut.

a. Madrasah 
Nama madrasah sebagai lembaga yang memfasislitasi transformasi ilmu telah mengalami pergeseran makna seiring perkembangan umat Islam saat ini. Pemaknaan Madrasah merujuk pada pendidikan non formal sampai pendidikan formal. Madrasah diakui sebagai salah tau jenis Lembaga pendidikan Islam disamping masjid dan pesantren. Asal kata Madrasah dalam bahasa arab adalah tempat belajar (Anis, 1972: 280). Isim makan masdrasah adalah "darasa" yang diartikan tempat duduk belajar. Istilah tersebut telah mengalami penyatuan dengan sekolah atau Lembaga pendidikan Islam (Poerwadaminta, 1990: 68).

Pendidikan Islam pada masa kolonial hanya terbatas pada Lembaga yang bersifat tradisional sebagaiman pesantren atau surau. Madrasah pertama yang berdiri di Indonesia adalah Madrasah Abadiyah. Madrasah tersebut didirikan Syekh Abdullah Ahmad tahun 1909 di Kota Padang, Sumatera Barat, didirikan oleh Syekh Abdullah Ahmad yang selanjutnya disusul berdirinya madrasah lain seperti Madrasah Shcool di Kota Batu Sangkar Sumatera Barat yang didirikan tahun 1910 oleh Syekh M. Talib Umar, sampai muncul Lembaga pendidikan yang menggabungkan sistem pendidikan Islam dan umum yang lahir dari organisasi Muhammadiyah oleh K.H. Ahmad Dahlan dkk serta munculnya Lembaga pendidikan yang menggabungkan system pesantren dan umum yang lahir dari organisasi Nahdlatul Ulama (NU) 1926 oleh K.H. Hasyim Asyari dan K.H. Wahab Hasbullah dan setelah itu madrasah mulai banyak tumbuh dan berkembang.

Pengaruh wacana pembaharuan pendidikan Islam dan kebangkitan pendidikan nasional menjadikan pelajaran umum secara perlahan masuk ke dalam kurikulum madrasah. Buku pelajaran agama mulai disusun sebagaimana buku pelajaran umum di sekolah untuk tingkatan madrasah. Hingga akhirnya muncul madrasah dengan bentuk sekolah modern yang menggunakan sistem perjenjangan seperti Madrasah Ibtidaiyah sampai Madrasah Aliyah yang sama dengan Sekolah Dasar sampai Sekolah Menengah Atas (Engku, 2014: 125).

b. Kurikulum Pesantren

Sebelum kita telaah lebih jauh terkait kurikulum pesantren, maka yang harus kita pahami bersama adalah model pesantren (termasuk pesanten salafi atau pesantren modern). Jika pesantren dalam hal ini mengembangkan model tradisional, maka kurikulum yang dibangun adalah mempertahankan pembelajaran khasnya yaitu pembelajaran kitab kuning. Pola pengajaran di pesantren menggunakan sistem "halaqah" yang dilaksanakan di masjid atau surau. Hakikat sistem halaqah adalah usaha menciptakan santri untuk menerima dan memiliki ilmu. Artinya ilmu yang diberikan tidaklah berkembang mengarah pada paripurna ilmu, akan tetapi terbatas dengan ilmu yang diberikan kyai. Termasuk kurikulum 
pesantren disusun dan kewenangan penuh Kyai sebagai pengasuh pesantren. Santri yang menetap di pesantren disebut santri mukim. Sementara santri yang tidak menetap disebut santri kalong (Sholihuddin, 2003: 18).

Selanjutnya adalah kurikulum pondok pesantren modern: Pondok pesantren ini merupakan pengembangan tipe pesantren karena orientasinya belajarnya cenderung mengadopsi seluruh sistem belajar secara klasikal dan meninggalkan sistem belajar tradisional. Penerapan sistem belajar modern ini terutama nampak pada penggunaan kelas-kelas belajar baik dalam madrasah maupun sekolah. Atau madrasah yang berlaku secara nasional. Santri pada pondok tipe tersebut ada yang menetap dan ada yang tersebar di sekitar desa. Perbedaannya dengan sekolah dan madrasah terletak pada porsi pendidikan agama dan bahasa Arab lebih menonjol sebagai kurikulum local. Adapun salah satu penerapannya dapat dilihat dari berbagai bidang yaitu: system klasikal yang sudah tersebut diatas, system pelatihan, dan kursus-kursus tertentu.

Dari penjabaran tersebut terkait madrasah, maka dipondok pesantren AlKaromah salah satu konsep pengembangannya adalah menerapkan konsep madrasah diniyah dengan mengambil beberpa klasifikasi pembagian dan pengembangan kurikulum madrasah diniyahnya, adalah pada "madrasah ula. Wustha dan ulya". Pengembangan kurikulum madrasah tersebut di jabarkan kembali dengan menggunakan konsep pengembangan makro, meso, dan mikro:

1) Kurikulum Makro

Segala bentuk kegiatan pendidikan di pesantren yang dirancang secara sistematis dan berkesinambungan untuk mencapai tujuan yang telah ditentukan. Adapun prinsip dasar pengembangan kurikulum MAKRO ini didasarkan pada tiga prinsip: Pertama, CONSENTRIS artinya kegiatan pendidikan di pesantren berpusat pada ajaran-ajaran Islam yang telah diajarkan oleh baginda Rasulillah saw, para sahabat-sahabat beliau dan salafuna assholihuun dan bersumber pada Al-Qur'an, Hadits sebagai sumber pokok serta Ijma' dan Qiyas.

Sedangkan dalam tradisi keilmuan pesantren lebih menekankan pada kajiankajian terhadap kitab-kitab klasik ( kitab kuning ) yang telah diwariskan oleh para ulama'-ulama' salaf. Kedua, CONTINYUITAS artinya kegiatan pendidikan di pesantren dilaksanakan secara konsisten / istiqomah sebagai upaya membentuk karakter para santri yang cerdas, religius serta berakhlak mulia dan berkesinambungan. Ketiga, CONVERGENSI artinya kegiatan pendidikan di pesantren tidak hanya mengajarkan dan mempelajari ilmu-ilmu agama secara teoritis saja akan tetapi pesantren juga mengembangkan aspek-aspek budaya yang tidak bertentangan dengan ajaran Islam dan budaya nasional 
2) Kurikulum Meso

Segala bentuk program kegiatan operasional pendidikan di pesantren yang disusun dalam upaya mencapai tujuan yang diharapkan. Adapun bentuk program kegiatan pendidikan di pesantren " PPAI AL KAROMAH " antara lain:

a) Program pendidikan Al-Qur'an: TPQ methode Qiroati, Binnadhri, dan Bilhifdzi (bilghoib)

b) Program pendidikan Madrasah: Madrasah Diniyah dan Takhoshshush Kitab kuning

c) Program pendidikan Ma'hadiyah (pesantren): Program Umum (tahunan dan bulanan) dan Program Khusus (Mingguan)

d) Program pendidikan Ubudiyah

e) Program pendidikan ketrampilan (life skill): Olahraga, Kewirausahaan, Bahasa Arab dan Inggris, Ilmu kemasyarakatan, dan BLK Komunitas Jurusan TIK ( Desain Grafis

3) Kurikulum Mikro

Segala bentuk kegiatan operasional (teknis) yang disusun secara sistematis dan detail pada masing-masing tingkat dan jenis kegiatan pendidikan di pesantren.

Pertama, pendidikan Al-Qur'an: pendidikan Al-Qur'an ini dibagi menjadi tiga jenjang /jenis yaitu:

a) Juz 'Amma (juz 30) bilghoib,program ini wajib bagi setiap santri baru dan ditempuh dalam waktu satu tahun. Adapun teknis pelaksanaan sbb:

1. Pendataan santri baru dan pembagian kelompok

2. Masing-masing kelompok berjumlah maksimal 15 santri dengan satu Ustadz (penanggung Jawab)

3. Masing-masing penanggung jawab (ustadz) sudah mempelajari dan menguasai target-target dari tiap-tiap surat yang akan dibacakan dan diajarkan, sehingga masing-masing kelompok memiliki kesamaan baik bacaan, surat ataupun yang lainnya.

4. Kegiatan ini dilaksanakan setiap hari dua kali, ba'da Shubuh (nambah materi/surat) dan ba'da Ashar mengulang/ deresan .

5. Durasi waktu pada setiap pertemuan/tatap muka -/+ 60 menit ( 1 jam )

b) Binnadhri 30 juz, program ini adalah merupakan kelanjutan dari program pertama yang harus ditempuh dan dikhatamkan oleh santri. Program ini ditargetkan khotam dua tahun (lancar dan mujawwad). Adapun teknis pelaksanaan sbb:

1. Santri dibagi menjadi tiga kelompok: kelompok pertama, juz 1-10, kelompok dua juz 11-20 dan kelompok tiga juz 21-30 
2. Masing-masing santri melaksanakan setoran Al-Qur'annya secara individu kepada penanggung jawab (ustadz) yang telah ditentukan pada masingmasing kelompok juznya dan antara kelompok satu, dua dan tiga adalah berkesinambungan dan berkelanjutan tujuannya adalah untuk mempermudah dan memepercepat proses pengkhotaman santri dengan lancar dan mujawwad.

3. Waktu setoran dilaksanakan setiap hari dua kali: ba'da Shubuh dan ba'da Ashar

c) Bilghoib 30 juz, program ini khusus bagi santri yang berkeingunan kuat untuk mengikuti program tahfidzul Qur'an dengan syarat telah khotam binnadhri 30 juz. Adapun teknis pelaksanaan:

1. Pendataan santri anggota tahfidz

2. Waktu setoran setiap hari kecuali hari Jum'at pagi dan sore / ba'da isya' ( deresan / sema'an )

Kedua, Madrasah Diniyah: Program ini terdiri dari tiga jenjang: Isti'dadiyah (persiapan), Madin Ula (tingkat dasar), Wustho (tingkat menengah) dan Ulya (tingkat atas).

a) Program isti'dadiyah

Program ini mempersiapkan para santri untuk memasuki jenjang Madrasah Diniyah sesuai dengan tingkatannya. Program ini dilaksanakan selama satu tahun dengan kompetensi:

1. Bidang Pengetahuan santri mampu memahami dan menghayati konsep dasar tentang ajaran Islam yang meliputi Al-Qur'an, ilmu Aqidah, Fiqih dan Akhlak.

2. Bidang psikomotorik santri dapat mempraktekkan ibadah dengan baik dan benar serta hafal doa-doa ba'dal maktubah dan harian serta mampu membaca dan menulis huruf arab pego.

3. Bidang sikap (Afektif) santri memiliki aqidah yang benar dan menjalankan ibadah dengan baik dan benar.

b) Madin Ula, mulai dari kelas I II dan III

c) Madin Wustho mulai kelas I II dan III

d) Madin Ulya mulai kelas I II dan III

Ketiga, Takhossus Kitab Kuning: Program ini diikuti oleh para santri senior yang telah lulus dari program Madrasah Diniyah Ulya dengan bidang kajian Aqidah, Fikih dan Akhlak.

Berikut adalah table 1 dan 2 contoh Struktur Kurikulum yang di kembangkan pada Madrasah Diniyah Wustha di Pesantren PPAI Al-Karomah. 


\begin{tabular}{|c|l|c|c|c|c|}
\hline \multirow{2}{*}{ No } & \multirow{2}{*}{ Mata Pelajaran } & \multicolumn{3}{|c|}{ Kelas } & \multirow{2}{*}{ Jumlah Jam } \\
\cline { 3 - 5 } & & I & II & III & \\
\hline 1 & Tafsir & 2 & 2 & - & 4 \\
\hline 2 & Fiqih & 2 & 2 & 4 & 8 \\
\hline 3 & Hadits & 2 & 2 & 2 & 6 \\
\hline 4 & Ilmu hadits & 2 & 2 & 2 & 6 \\
\hline 5 & Tajwid & 2 & 2 & 2 & 6 \\
\hline 6 & Tauhid & 2 & 2 & 2 & 6 \\
\hline 7 & Nahwu & 2 & 2 & 4 & 8 \\
\hline 8 & Shoroof & 2 & 2 & 4 & 8 \\
\hline 9 & Akhlaq & 2 & 2 & 2 & 6 \\
\hline 10 & Tarikh & 2 & 2 & 2 & 6 \\
\hline 11 & Imla'/Mahfudhoot & 4 & & & 4 \\
\hline \multicolumn{2}{|l|}{ Jumlah jam } & 24 & 20 & 24 & 68 \\
\hline
\end{tabular}

Tabel 1. Sebaran Jam Mata Pelajaran

\begin{tabular}{|c|c|c|}
\hline No & $\begin{array}{c}\text { Mata Pelajaran dan Tujuan } \\
\text { Pembelajaran }\end{array}$ & $\begin{array}{l}\text { Kitab yang digunakan sesuai } \\
\text { jenjang/kelas }\end{array}$ \\
\hline 1 & $\begin{array}{l}\text { Tafsir Al-Qur'an: santri diharapkan } \\
\text { mampu memahami dan menghayati } \\
\text { ayat-ayat Al-Qur'an baik secara lafdzi } \\
\text { maupun secara ma'nawi. }\end{array}$ & $\begin{array}{l}\text { Tafsir Jalalain } \\
\text { Tafsir surah Al Ikhlash } \\
\text { Tafsir surah Al Fatihah } \\
\text { - Tafsir Juz 'Amma } \\
\text { Tafsir Ibriz }\end{array}$ \\
\hline 2 & $\begin{array}{l}\text { Fiqih: santri diharapkan mampu } \\
\text { memahami dan mengaplikasikan } \\
\text { ajaran Islam dengan baik dan benar. }\end{array}$ & $\begin{array}{l}\text { Fiqhul Wadlih } \\
\text { Mabadiul Fiqhiyah 1-4 } \\
\text { Fathul Qorib } \\
\text { Fathul Mu'in }\end{array}$ \\
\hline 3 & $\begin{array}{l}\text { Hadits: santri diharapkan mampu } \\
\text { memahami, menghayati dan } \\
\text { menghafal sekaligus mengamalkan } \\
\text { hadis-hadis Nabi. }\end{array}$ & $\begin{array}{l}\text { Hadits } 101 \\
\text { Washiyatul Musthofa } \\
\text { * Arba'in Nawawi } \\
\text { Bulughul Maroom } \\
\text { Riyadhus Sholihiin }\end{array}$ \\
\hline 4 & $\begin{array}{l}\text { Ilmu Hadits: santri mengenal dan } \\
\text { memahami ilmu mustholah hadis } \\
\text { sehingga dapat membedakan hadis } \\
\text { yang sohiih, hasan dan dloif. }\end{array}$ & $\begin{array}{l}\text { Minhatul Mughits } \\
\text { Mustholahul Hadits }\end{array}$ \\
\hline 5 & $\begin{array}{l}\text { Tajwid: santri diharapkan mampu } \\
\text { memahami hukum-hukum bacaan Al- } \\
\text { Qur'an dan membaca Al-Qur'an } \\
\text { dengan baik dan benar sesuai kaidah } \\
\text { tajwid (Mujawwad) }\end{array}$ & $\begin{array}{l}\text { Syifa'ul Jinan } \\
\text { Tuhfatul Athfaal } \\
\text { Hidayatul Mustafidz } \\
\text { Fathul manan }\end{array}$ \\
\hline
\end{tabular}




\begin{tabular}{|c|c|c|}
\hline 6 & $\begin{array}{l}\text { Ilmu Tauhid: santri diharapkan } \\
\text { mampu memahami dan menghayati } \\
\text { arti tauhid dan mengaplikasikannya } \\
\text { dalam kehidupan sehari - hari }\end{array}$ & $\begin{array}{l}\text { * Aqidatul awam } \\
\text { Khoridatul bahiyah } \\
\text { * Aqidatul Islamiyah } \\
\text { Jawahirul kalamiyah } \\
\text { Husunul hamidiyah } \\
\text { Kifayatul awam }\end{array}$ \\
\hline 7 & $\begin{array}{l}\text { Ilmu Nahwu: santri diharapkan } \\
\text { mampu memahami dan menerapkan } \\
\text { kaidah-kaidah nahwiyah untuk } \\
\text { memahami bahasa kitab kuning ( } \\
\text { Bahasa Al-Qur'an ) dengan baik dan } \\
\text { benar. }\end{array}$ & $\begin{array}{l}\text { Nahwul Wadlih } \\
\text { Matan Jurumiyah } \\
\text { Matan Imrithi } \\
\text { Alfiyah Ibnu Malik }\end{array}$ \\
\hline 8 & $\begin{array}{l}\text { Ilmu Shorof: santri diharapkan } \\
\text { mampu memahami perubahan- } \\
\text { perubahan bentuk kalimat ( dalam } \\
\text { bahasa Al-Qur'an ) untuk mencari } \\
\text { makna yang sesuai ataupun yang } \\
\text { dikehendaki }\end{array}$ & $\begin{array}{l}* \text { Amtsilatu Attashrifiyah } \\
\text { Qowa'idul I'lal } \\
\text { Nadhom Maqshud }\end{array}$ \\
\hline 9 & $\begin{array}{l}\text { Ilmu Akhlaq: santri diharapkan } \\
\text { mampu memahami dan menghayati } \\
\text { urgensi akhlak dalam kehidupan } \\
\text { sehari-hari ( baik akhlak terhadap } \\
\text { Alloh swt, RasulNya, diri sendiri, orang } \\
\text { lain ataupun lingkungan ) juga } \\
\text { sekaligus menerapkan dalam } \\
\text { kehidupan sehari-hari. }\end{array}$ & $\begin{array}{l}\text { Ta'limul Muta'allim } \\
\text { Washooyaa } \\
\text { *anbihul Muta'allim } \\
\text { * Akhlaaqul Banaat } \\
\text { * Taisiirul kholaaq }\end{array}$ \\
\hline 10 & $\begin{array}{l}\text { Tarikh: santri diharapkan mampu } \\
\text { memahami, menghayati,menceritakan } \\
\text { sejarah Nabi, para Sahabat dan sejarah } \\
\text { hukum-hukum Islam }\end{array}$ & $\begin{array}{l}\text { * Tarikh Nabi } \\
\text { * Khulashoh Nurul Yaqiin } \\
\text { Tarikh Tasyrii' }\end{array}$ \\
\hline
\end{tabular}

Tabel. 2 Jenis Kitab yang Digunakan

\section{Manajemen Pesantren PPAI Al-Karomah}

Persoalan mutu pendidikan hari ini adalah selaras dengan tuntutan perkembangan dan perubahan. Suatu perubahan menuntut peran agen pembaharuan (the agent of change) dalam memunculkan ide-ide gagasan dalam pembaharuan serta mengupayakan pengelolaan yang baik. Sosok agen perubahan secara internal dan eksternal pada lembaga pendidikan yang dimaksud adalah adanya sosok pemimpin yang menjalankan kepemimpinan secara baik. yaitu kepemimpinan yang mampu memanaj segenap sumber daya manusia dan sumberdaya lainnya di lembaga yang dipimpinnya menuju visi dan misi yang dicita- 
citakan bersama (Nurdin, 2007: 239). Dalam hal ini adalah sumberdaya manusia yaitu pendidik dan tenaga kependidikan yang berkaitan dengan berbagai persoalan, diantaranya persoalan kualifikasi, pembinaan dan pengembangan keprofesionalan pada pesantren tersebut. Sehingga dibutuhkanlah kinerja yang baik dengan adanya arahan, bimbingan, intensif dan berkelanjutan sehingga betul-betul mampu menjalankan segenap tugas, fungsi dan tanggung jawabnya secara profesional, selaras dengan tuntutan standar pendidik dan tenaga pendidikan yang dipersyaratkan dalam dunia pesantren.

Banyak tipe dan gaya masing-masing individu dalam memimpin, dalam hal ini adalah (termasuk kepemimpinan kiai) Ciri khas santri sangat erat dengan proses interaksi dan komunikasi yang terjadi antara pimpinan (top up) dan bawahan (top down) yang dipengaruhi oleh efektifitas pimpinan yang dalam hal ini adalah penulis sebut kepemimpinan kiai. Dalam hal ini penulis meminjam topik bahasan bahwa Proses dari formulasi kebijakan menurut teori ini, secara top down membuat kebijakan publik untuk diimplementasikan oleh administratur publik kepada rakyat atau masyarakat inilah definisi secara manajemen (Ismail, 2017: 3). Disinilah sering kebijakan top up itu dilaksanakan langsung oleh seorang kiai dalam memutuskan sebuah kebijkan dalam pengembangan pesantren yang dipimpinnya.

Dalam dunia pesantren, manajemen yang dibangun adalah pola kepemimpinan kiai merupakan manajer tertinggi, selanjutnya adalah keluarga pesantren, dan terakhir adalah pengurus pesantren.

a. Pola kepemimpinan kyai

Dalam budaya pesanten, seorang kiai dianggap memiliki berbagai peran, baik sebagai pemimpin para santri. Posisi kiai sebagai pemimpin pesantren juga diharuskan untuk menjunjung tinggi nilai-nilai luhur yang menjadi acuan dalam perilaku dan pengembangan pesantren (Madjid, 1995: 465).

Kepemimpinan kyai di pesantren Al-Karomah bersifat kharismatik hal tersebut dapat penulis amati dari berbagai progam yang dilaksanakan dipesantren, serta dapat dilihat secara langsung dari cara kyai memanaj beberapa kegiatan dan progam pesantren yang berjalan lewat pengurus pondok dan secara langsung beliau sendiri juga yang berperan aktif didalam kegiatan dan progam pesantren yang berjalan.

Kepemimpinan harismatik pesantren memiliki nilai lebih tersendiri sebagai salah satu tipologi kepemimpinan. Salah satu indikatornya adalah kebesaran pengaruh terhadap pengikutnya. Kepemimpin tersebut tidak mudah dibentuk begitu saja, akan tetapi lahir dengan sendirinya karena terdapat kelebihan psikis maupun mental yang dapat membuat orang terpengaruh dan mengikuti apa yang 
diperitahkan dengan mengesampingkan aspek rasionalitas. Model kepemimpinan seperti ini sebagaimana yang terdapat pada pesantren Al-Karomah kepanjen malang.

Di pesantren Al-Karomah, fenomena kepemimpinan kyai dipandang sebagai hal unik berdasarkan tugas dan fungsinya. Alasannya tugas kyai tidak membuat kurikulu, merancang tata tertib, membuat system evaluasi dan mengajar kepada santri tentang ilmu agama, melainkan juga bertugas membina dan mendidik masyarakat (Arifin, 1996: 57). Sedangkan pandangan Tholhah Hasan menampilkan empat macam tugas kepemimpinan kyai, diantaranya: 1) pemimpin masyarakat (community leader) bilmana kyai memiliki peran memimpin organisasi, 2) Pemimpin keilmuan (intellectual leader), bilmana kyai mengajarkan ilmu agama dan sesuai kapasitas keilmuannya, 3) Pemimpin kerohanian (spiritual leader) bilamana kyai memimpin kegiatan ritual ibadah dan panutan moral, dan 4) Pemimpin administratif, bilmana kyai terlibat dalam pengelolan Lembaga pendidikan maupun lembaga lain dan bertanggung jawab atas Lembaga yang dipimpinnya (Hasan, 1992: 25). Dan dari pengamatan peneliti pengasuh pesantren Al-Karomah selain memiliki kharismatik yang kuat, tipe kepemimpinan beliau juga berperan sebagai pemimpin keilmuan pada point kedua dan pemimpin masyarakat pada point kesatu, Serta menjadi kerohanian.

\section{Simpulan}

Dari pemaparan penulis, dapat diambil kesimpulan tipologi manajemen lembaga pendidikan Islam di Nusantara (studi kasus di pondok pesantren AlKaromah kepanjen malang) terlihat dari pengembangan pesantren yang lebih cenderung kepada pengembangan pesantren secara modern, hal ini bisa dilihat dari hasil penelitian yang penulis laksanakan yaitu terlihat dalam kurikulum pesantren yang pengembangannya cenderung kepada mengembangkan madrasah diniah yang terbagi menjadi madrasah diniyah tingkat ula, wustha, dan ula. Tidak hanya pengembangan madrasah diniah saja, dalam pengembangan kurikulum yang ada di pesantren Al-Karomah mengembangkan kurikulum pesantren yang bersifat makro, meso dan mikro.

Selanjutnya pada pola kepemipinan yang diperankan kyai di Pesantren AlKaromah langsung di asuh oleh Kyai Mudhoffir Murtadlo terlihat beliau dalam menjalankan kepemimpinan dipesantrennya lebih kepada tipe kepemimpinan kharismatik, hal ini terlihat dibeberapa struktur kegiatan yang melibatkan sosok kyai secara langsung dilapangan. Selain tipe kharismatik, kyai di pesantren AlKaromah terlihat bereperan sebagai sebagai pemimpin keilmuan (intelectual 
leader), sebagai pemimpin masyarakat (community leader), Serta menjadi pemimpin kerohanian (spiritual leader).

\section{Daftar Rujukan}

Arifin, Imron. (1996). Penelitian Kualitatif dalam ilmu-Ilmu Sosial dan Keagamaan. Malang: Kalimasahada Press.

Arikunto, Suharsimi. (2002) Prosedur Penelitian Suatu Pendekatan Praktek. Jakarta: PT. Rineka Cipta.

Bugin, Burhan. (2001). Metodologi Penelitian Sosial. Surabaya. Airlangga Universitas Press.

Danim, Sudarwan. (2002). Menjadi Peneliti Kualitatif Rancangan Metodologi. Presentasi. dan Publikasi Hasil Penelitian untuk Mahasiswa dan Penelitian Pemula Bidang Ilmu Sosial, Pendidikan, dan Humaniora. Bandung: Remaja Rosdakarya.

Daulay, Haidar Putra. (2002). Pendidikan Islam dalam Sistem Pendidikan Nasional Medan: IAIN Press. cet. 1.

Diding, Nurdin.. (2007). “Manajemen Pendidikan” dalam Djudju Sudjana dkk. Ilmu dan Aplikasi Pendidikan. Jakarta: Grasindo.

Engku, Iskandar \& Siti Zubaidah. Siti. (2014). Sejarah Pendidikan Islami. Bandung: PT. Remaja Rosda Karya

Fadjar, A. Malik. (1999). Madrasah dan Tantangan Modernitas. Bandung: Mizan. Cet. 2.

Hasan, Tolhah. (1993) dalam Pengantar Imron Arifin. Kepemimpinan Kyai: Kasus Pondok Pesantren Tebuireng. Malang: Kalimasahada.

Ibrahim Anis. et-al. (1972). Al-Mu'jam al-Wasit. Kairo: Dar al-Ma'arif.

Ismail. (2017). Politik pendidikan Islam disaerah (Studi Kebijakan Pemerintah Provinsi Jawa Timur Dalam pengembangan madrasah diniyah. Surabaya: Pascasarjana Universitas Islam Sunan Ampel Surabaya.

Majid, Nurcholis. (1995). Bilik-bilik Pesantren: Sebuah Potret Perjalanan. Jakarta: Paramadina.

Malayu. SP Hasibuan. Manajer:Dasar. Pengertian. dan Masalah. Jakarta: Bumi Aksara: 2001)

Maunah, Binti. (2009). Tradisi Intelektual Santri: Dalam Tantangan dan Hambatan Pendidikan Pesantren di Masa Depan. Yogyakarta: Teras.

Moleong, Lexy. J. (2000). Metodologi Penelitian Kualitatif. Bandung: PT Remaja Rosdakarya.

Nata, Abuddin. (2011). Sejarah Pendidikan Islam. Jakarta: Kharisma Putra Utama. 
Poerwadaminta, WJS. (1990). Kamus Umum Bahasa Indonesia. Jakarta: Balai Pustaka.

Qomar, Mujamil. (2007). Manajemen Pendidikan Islam. Jakarta: Erlangga.

Sa'dullah, Anwar \& Muhammad Fahmi Hidayatullah. 2020. Design Of Improving The Quality Of Human Resources Based On Islamic Schools In Anak Saleh Foundation, Malang City. Nazhruna: Jurnal Pendidikan Islam Vol. 3 No. 2.

Sholihuddin, Moh. Kurikulum Pesantren dan Pemberdayaan Masyarakat. Jurnal Al'Adalah Vol. 6. No. 1. April 2003.

Soebahar, Abdul Halim. (2013). Modernisasi Pesantren. Yogyakarta: Lkis.

Sugiyono. (2008) Metode Penelitian Pendidikan Pendekatan Kuantitatif, Kualitatif, dan R\&D. Bandung: Alfabeta.

Sutopo. Administrasi. (1999) Manajemen dan Organisasi. Jakarta: Lembaga Administrasi Negara.

Umiarso \& Zazin, Nur. (2011). Pesantren di Tengah Arus Mutu Pendidikan: Menjawab Problematika Kontemporer Manajemen Mutu Pesantren. Semarang: RaSAIL Media Group.

Usman, Husaini \& Akbar, Purnomo Setiadi. (2009). Metodologi Penelitian Sosial. Jakarta: PT Bumi Aksara. 